\title{
An active dressing prevents formation of Staphylococcus aureus biofilm on a mucosal surface
}

\author{
P Parks ${ }^{1 *}, M_{\text {Anderson }}^{2}$, M Peterson $^{2}$ \\ From International Conference on Prevention \& Infection Control (ICPIC 2011) \\ Geneva, Switzerland. 29 June - 2 July 2011
}

\section{Introduction / objectives}

An antiseptic containing dressing is used to minimize the risk of nosocomial infections including Staphylococcus aureus, which can invade via skin or mucosal surfaces. This study developed a mucosal model of S. aureus biofilm formation and determined the effect of the active dressing (Tegaderm ${ }^{\text {TM }} \mathrm{CHG}$ ) on biofilm formation and mucosal integrity.

\section{Methods}

Explants of normal porcine vaginal mucosa (full-thickness) were infected with biofilm-producing methicillinresistant S. aureus (MRSA) $\left(3.2 \times 10^{\wedge} 5 \mathrm{CFU}\right)$ for $2 \mathrm{~h}-$ $48 \mathrm{~h}$. Following infection ( $2 \mathrm{~h}$ ), explants were treated with the active dressing (Tegaderm ${ }^{\mathbf{T M}} \mathrm{CHG}$ ) for $22-46 \mathrm{~h}$ or left untreated (controls). Formation of MRSA biofilm was evaluated by scanning electron microscopy. Also, bacteria were enumerated from infected explants, which were washed $3 x$ in PBS by vortex mixing and compared to unwashed explants, to determine the effects of the active dressing (Tegaderm ${ }^{\mathbf{T M}}$ CHG) on MRSA growth.

\section{Results}

MRSA exhibited typical growth on porcine vaginal mucosa. MRSA recovered from infected mucosa at $24 \mathrm{~h}$ were mainly adherent [washed (adherent): 6.71 \pm 0.07 ; vs. total (planktonic + adherent) $8.27 \pm 0.06 \log 10 \mathrm{CFU} /$ explant]. Biofilm was evident on MRSA-infected vaginal mucosa at $24 \mathrm{~h}$ via SEM, and MRSA disrupted the integrity of the mucosal surface. Active dressing (Tegaderm ${ }^{\mathbf{T M}}$ $\mathrm{CHG}$ ) exposures for $24 \mathrm{~h}$ reduced the number of MRSA to $3.44 \pm 1.00$ vs. untreated controls $7.90 \pm 0.00 \log 10 \mathrm{CFU} /$

${ }^{1}$ Exp Clin Pharmacol, 3M/UnivMinn, Minneapolis, USA

Full list of author information is available at the end of the article explant. At $48 \mathrm{~h}$, no bacteria were detected in the active dressing (Tegaderm ${ }^{\mathbf{T M}} \mathrm{CHG}$ ) treated group compared to untreated controls $7.96 \pm 0.15 \log 10 \mathrm{CFU} /$ explant.

\section{Conclusion}

MRSA biofilms can form on normal healthy mucosal tissue. An antiseptic containing active dressing (Tegaderm $^{\text {TM }}$ CHG) prevented MRSA biofilm formation.

\section{Disclosure of interest}

None declared.

\section{Author details}

${ }^{1}$ Exp Clin Pharmacol, 3M/UnivMinn, Minneapolis, USA. ${ }^{2}$ ExpClinPharmacol, Univ Minnesota, Minneapolis, USA.

Published: 29 June 2011

doi:10.1186/1753-6561-5-S6-P62

Cite this article as: Parks et al:: An active dressing prevents formation of Staphylococcus aureus biofilm on a mucosal surface. BMC Proceedings 2011 5(Suppl 6):P62.

Submit your next manuscript to BioMed Central and take full advantage of:

- Convenient online submission

- Thorough peer review

- No space constraints or color figure charges

- Immediate publication on acceptance

- Inclusion in PubMed, CAS, Scopus and Google Scholar

- Research which is freely available for redistribution 